\title{
Why do we need a cultural economics? History and development of the field
}

Samuel Cameron

\section{Introduction}

Critical, evaluative and forward-looking reviews of research in cultural economics are comparatively rare. In fact, even reviews of sub-fields within the subject are also quite rare. Such papers tend to be confined to editorial introductions to special issues in the Journal of Cultural Economics, other works of a general and referential nature, and some of the volumes in Edward Elgar Publishing's International Library of Critical Writings in Economics series (see, e.g., Ginsburgh 2001; Ginsburgh and Throsby 2006; Towse 2006, 2011). Some overview material is to be found in textbooks in the field but these tend to be restrained by the need to promote the merits of the topic in the first instance. I will discuss the layout of cultural economics textbooks below, following a review of the role of culture in the history of economic ideas.

Given the situation, it is still worth reading the survey of the field by Throsby (1994) which identifies key themes up to that time and the progress that had been made in them. Since 1994, the key impact on cultural economics, in the real world, has been the emergence of digital production and consumption, more specifically via different forms of internet activity. This might be subsumed within general ideas about the knowledge economy and intellectual property, but there are still questions about whether fundamental changes in thinking are needed to deal with some of the impact of the changes. Digital production and consumption was apparent by 1994 in such things as CDs, DVDs, minidiscs, and the use of software in music and film production. File sharing and downloading were not issues, although physical copying was a long-standing issue arising mainly from cassette and VHS tape in the form of 'bootlegs'.

Digital hardware disc formats were just gradual evolutions within the conventional styles and modalities of delivery. They did not spark any call for new thinking in terms of analysis of markets. The more recent digital and internet changes are a greater problem as they challenge many of the foundations of the whole of economics. One might think that cultural economists would be well placed to embrace this challenge. The following chapters in this book address this across a range of themes. I shall return to more detailed discussion of the contents of the Throsby 
paper at the end of this chapter, as it takes us into the matters to be concerned in the next chapter.

So far, there has been little concern with the position of cultural economics in the history of economic ideas, so I devote some time to that in this chapter. We might naively think that if cultural economics is important then all major economists and dominant schools of thought would have made significant contributions to it throughout the history of economics. The field of cultural economics has been established for quite a long time but is very new as a distinct field of economics compared with, say, international trade or public finance. Further, it might be argued that it could be construed as simply some arbitrary parts of public finance and industrial economics lashed together into a makeshift structure held together by a common interest in culture. In terms of traditional mainstream economics divisional areas, it is in the field of welfare economics that cultural economics has seen most of its significant theoretical action; most notably in terms of the justification for subsidies, the most efficient delivery mode for them and their allocation. However, the subsidy field has seen a general tendency to rehash the same basic points in favour of subsidy which are well documented in the antisubsidy pamphlet from the Institute of Economic Affairs (IEA) (Sawers 1993). The biggest ongoing weakness of such theoretical arguments is a yawning chasm of corresponding empirical evidence; one struggles in vain to find aggregate quantification of most of the positive externalities attributed to cultural consumption and production. However it might be argued that the incursion of the current vogue for trying to explain 'happiness' (social well-being) into cultural economics (see Michalos and Kahlke 2008 for an early example of this) is filling some of this gap to a greater degree than the willingness-to-pay valuation studies of cultural heritage of the past.

Current academic journal literature in the field tends to stay away from the subsidy issue, and is primarily focused on narrower empirical works on supplier and consumer behaviour which sometimes include the effect of subsidies on these. That is, there is a focus on the positive not the normative side of the subsidy issue.

\section{The history of cultural economics as an idea}

In this section, I look at the place of cultural economics in the history of ideas. The presentation is not a linear one which simply recounts who said what on what date in a sequential manner. Rather, it is thematic, so I will take off at various points to related matters in more recent and modern-day thinking. To some extent this will be a litany of non-events (that is, that people did not contribute to cultural economics), but this is still useful in contextualizing the nature of the field and identifying the future agenda for its progression.

In terms of looking for culture in the history of economic ideas, we are concerned with human activities that exist to provide utility beyond subsistence and simple 
functionality. If we take the modern example of a car: if it is purchased merely to get the person from a to $b$, where $b$ is the place of work, and has no other role, then it would seem not to involve cultural economics. If music is played in the car or radio is listened to, then cultural activity is taking place in the car. What if the car is providing utility from its general appearance aesthetically, or indeed negative utility from a poor aesthetic? It then appears to be part of the cultural economy. We may go further and note that cultural works such as music or films may be made about the car directly, or the car may feature metaphorically and symbolically in works of art such as the film The Cars That Ate Paris (1974) or the song 'Little Red Corvette' (1983) by Prince. Pursuing this line, it would seem that almost anything consumed or produced is cultural in nature; for example, we could have given a similar discussion about food. Thus we can end up in either of two opposite positions: that all economics is cultural economics anyway so there is no need for a separate field, or that if all economics is cultural then the type of analysis typically undertaken by mainstream economists needs to be changed to a wider type of investigation that takes more account of the social nature of human behaviour.

The development of economic ideas in general has delivered a varying degree of tension for the idea that culture as understood here can be legitimately analysed within economics. The roots of economics are in religion and Socratic dialogue, but formalization into a body of professional doctrine was slow. The pre-Enlightenment economics of mercantilism had little to say on the subject of culture as an independent entity, as its sole focus was on making money through buying cheap and selling dear. So culture is like anything else if you can buy it cheap and sell it dear, and in this case to another nation, which is a good thing. This kind of thinking can be seen in the history of some fields such as the exploitation of musicians, actors, authors and other culture content providers. However modern welfare economics would not dogmatically claim that it is a good thing for the consumer to benefit from low prices and low wages in cultural production. Basically we would get the 'killing the goose that lays the golden eggs' argument, which is manifest in some discussions of the effective collapse of prices to near zero for some digital media products due to copyright infringement as a result of technical innovation in terms of sharing, streaming and downloading. Also, the basic 'lay' view of ticket touting or scalping is essentially mercantilism, as opposed to the more sophisticated modern neo-classical economics view of it as a useful arbitrage activity that brings Pareto improvements (Courty 2000, 2003).

\section{Physiocracy and the labour theory of value}

A fundamental question is: why do cultural goods have value at all? The eighteenthcentury French Enlightenment gave us the 'origin of value' ideas of the Physiocrats. They saw the origin of value in agricultural land. The appropriation of origin of value ideas to labour, by Marx via Ricardo, seemed to bring the death knell of this approach thanks to the emergence of subjective utility in the work of Jevons and Austrian economists. Cultural goods would only have value if consumers place high 
enough value on them to generate a market price for them. Otherwise the cultural worker is wasting their time and effort unless this is producing high enough returns to them personally in terms of utility to justify the activity.

Surprisingly, origin of value ideas resurface from time to time, sometimes in the inverted form that there is a parasitic sector which is simply appropriating value, not creating it. It did not have a specific reference to culture, but the macroeconomic work of Bacon and Eltis (1976), which was in vogue during the period of great stagflation in the United Kingdom (UK), resurrected some degree of physiocracy in an attempt to explain slow growth and poor general economic performance. That is, there are some parasitic sectors of the economy which do not produce 'real' output. The idea of a parasitic drag on the economy also rears its head in some econometric work on the burdening of the economy by litigation and excess numbers of lawyers (see Cameron and Thorpe 2004). This charge has not been levied at the cultural sector, but the withdrawal of subsidy to it, from governments, in difficult macroeconomic times as a lower priority than the economy of the 'real' productive sector, is imbued with some elements of it.

Although seldom remarked upon (but see the discussion in Cameron 2011) the recent vogue for the idea of a creative class in the creative economy led by the work of Richard Florida (2002) smacks of physiocracy and in so doing reverses the 'parasitic' scenario. The argument has been projected to the macro level to suggest that economies with more creative workers have higher growth. Florida's core evidence was based on cross-section regressions of local economic activity on 'funky' neighbourhood proxies such as 'gayness' or bohemian-ness. He looks at comparative growth rates in states of the United States of America. There are problems here of concept measurement and causality. Florida's work seems to have been quite influential in some countries. For example, in the UK, politicians have been keen to claim that the supposed national superiority in creativity can spark an economic renaissance. This kind of claim has also been prevalent in local economic development circles, perhaps peaking in the pursuit of 'City of Culture' status. These matters, and the impact of Florida on cultural economics in general, can be studied further in the text by Towse (2010).

The next step forward in terms of relevant economic thinking, after physiocracy, was the 'labour theory of value', which would effectively be knocked down by the emergence of subjectivist writings based on the determination of price by marginal utility. The labour theory of value did not take hold within the nascent science of economics, or 'political economy' as it was then known, until after Adam Smith's much more broad-ranging work.

\section{Adam Smith}

Adam Smith is still regarded as the founding father of economics, particularly for his work in the Wealth of Nations (Smith 1776 [1976]), although the key idea of the 'invisible hand' was expounded in his Theory of Moral Sentiments (Smith 1759 
[1976]). For cultural economics, the invisible hand idea in its crudest form would seem to suggest that there is no need for special protection of culture from markets, as the price mechanism will suffice to allocate all things optimally. Smith rejected source of value ideas in terms of culture, as he went into some detail in explaining that the work of an artistic labourer, such as a singer or dancer, was a genuine source of value if it provided utility to the consumer. Thus it was not a function of the amount of training and practice and work that the singer and dancer did. Smith did not, however, seek to argue that there was anything extra or special about cultural activities in terms of their impact on consumers.

Despite the enormous importance attached to Smith in the history of economics, the subsequent trend in economics was a move away from his wide-ranging appraisal of the whole economic system towards more specifically focused views. The intellectual content was somewhat paradoxical, as the notion of utility was politically important but not a basis for explanation of economic value, which was rooted in the labour theory of value and thus diverted the 'origin in a source' approach from land to the human factor in general. The bedrock of this was the work of Jeremy Bentham, which David Ricardo took into a more coherently argued economic analysis of specific problems of the day. The archetypal form of this is founder Jeremy Bentham's remark that 'pushpin is as good as poetry', thereby denigrating the arts and culture and emphatically, it seems, stating that there would be no need for a separate cultural economics.

A key Ricardian thinker was James Mill, who is most relevant here for the impact on his son John Stuart Mill. In his autobiography (Mill 1873 [2018]), he details how his life was dominated by his father's indoctrination of a dour version of utilitarianism: that only things that were practically useful, mattered. Under the influence of Harriet Taylor, J.S. Mill recanted on his strict upbringings and produced a hefty, but ambiguous, work on economics which watered down Ricardian doctrines without going on to provide a clear direction for the future of the subject. His personal struggles appear to have triggered a nervous breakdown. However this did not bring any cultural refocusing of the scope of 'political economy', despite the fact that his crisis was stimulated by anxiety about the future death of music. Mill's crisis is discussed in Chapter 3 of Cameron (2015), where the 'death of music' anxiety is formulated in terms of standard neo-classical welfare economics.

\section{Humanist critics}

The demise of Ricardianism can be linked to the problems brought in the wake of its adoption by Karl Marx. Marx was a social and political critic attempting to subvert the dominant economic theories of his day for his own purposes. He saw that humans had great creative potential as organic beings, and therefore his ultimately utopian socialism must logically include the idea that all beings would engage in enriching cultural activities where the boundaries between production and consumption would shrink. The idea of blurring between consumption and production was taken up by the French sociologist Pierre Bourdieu (1984, 1986). His work 
gains some attention in more discursive works on cultural economics, although most maintain the strict production-consumption schism that is manifested in the textbooks and survey works cited above. Bourdieu's emphasis on the production-consumption boundary dissolving is not really addressed by the Becker (1965) model of household production which is, understandably, popular in cultural economics. Technological change has significantly undermined the barrier, especially in the fields of broadcasting, music and film.

Enthusiastic consumers can turn into producers, particularly easily in the field of radio where 'guerilla' stations that would have previously been subject to piracy laws can operate via websites. These can even have a greater reach than official broadcasters, due to escaping the 'geoblocking' imposed on such as the BBC for some content. They can also provide real-time visual coverage of their activities on Facebook Live. Consumer musicians and film makers can easily turn into producers due to falling input prices, easier sampling of work by others, and so on.

Marx did not contribute anything to the analysis of cultural economics per se, but he did highlight the conflict between economics and culture. That is, the profit motive and competition drove individuals to be primarily trapped in work time that was generally not imbued with cultural meaning. This theme was taken up by Herbert Marcuse (see Geoghegan 1981) in a more lofty exegesis of the kind of learned irrationality argument put forward in modern empirical work seeking to demonstrate that some individuals impair their well-being by watching too much television (Frey et al. 2007). Marcuse maintained that individuals had a 'psychic thermidor' that prevented them from fully indulging and enjoying their hedonistic impulses. Framed in terms of conventional neo-classical welfare economics, some form of (to a large degree self-imposed) inhibition lowers the feasibly attainable level of social welfare. For cultural activities, the Marcusian position would be that an individual denies themselves culture almost out of guilt that they may be having too much fun, and may lose their capacity to work and function normally. Of course, some cultural movements fuelled by recreational drugs have sought to bring about the opposite situation, where life becomes non-stop fun. Such movements have eventually been controlled and absorbed into mainstream market culture. The analysis of how this has happened has not been a part of typical cultural economics research as it strays more into media studies and the notion of 'political economy' adopted currently by non-economists.

Many non-left-wing social thinkers in Britain were disturbed by the implications of the industrial revolution. These include the novelist Charles Dickens and the essayist Thomas Carlyle (see Balestrino 2011). Unlike John Stuart Mill, they were not fettered by a legacy of Ricardian economics and thus did not have to wrestle with theories of value. As they did not anticipate the rise of consumer theory they also did not have to deal with the demand argument. So, from its title, the chief relevant humanist critical work would seem to be 'A Joy Forever', which was the text of two lectures on the political economy of art given in Manchester in 1857 (Ruskin 1857 [1905]). The term 'political economy' is what economics was still called before the 
work of Alfred Marshall. Ruskin's views on economics lay neglected for a long time, until there began a trickle of publications (Henderson 2000; Winch 2000; May 2010; Lim 2011; Throsby 2011) in the present century initially sparked by calls for papers on the centenary of his birth.

There is a clear division in the views found in this literature, although all of these focus on the same elements in their exposition of the content of Ruskin's work that is relevant to economics, and they also agree in their interpretations of what he said. The division is between those who see Ruskin as offering a genuine challenge which flags the need for change, or just an amusing and entertaining work which is worth reading, which is largely what Throsby (2011, p. 291) says: 'it would be going too far to anoint him the founding father of contemporary cultural economics. Nevertheless there is much enjoyment and enlightenment to be gained from a reconsideration of his maverick views in this field.'

Ruskin is best known for his involvement in the visual arts, and it is this which inspires the contribution in these 1857 lectures. Here, he explores the question of the value of artistic labour in terms of genius, art education, art collecting, private and state patronage, and art's accessibility to the public. He expresses himself in a trenchant manner befitting of a modern 'Twitter storm' so far as the established workers in political economy are concerned. He uses much colourful and insulting language about the subject in general, and specifically towards the unfortunate John Stewart Mill. It is regrettable in terms of the early development of cultural economics that some full and frank debate on the role of culture in economics did not take place between these two. It seems clear that Ruskin's ire is due to a stereotypical view of all economists as mere 'bean counters' and apologists for capitalism, as opposed to being meaningful social critics.

Ruskin aroused the anger of visual artists due to his position that they were like children who needed to be looked after with literal (as well as financial) patronage by the state or an individual patron, depending on the circumstances. This sparked countervailing activity as they created new organizations and influenced exhibition venues in a wave of activity from 1880 to 1914 that resulted in the movement to professional status of their occupation. Similar movements took place with musicians becoming unionized.

Ruskin believed the state must find and train geniuses, thereby providing them with the relevant human capital to overcome the market failure in the genius market. Ruskin was also concerned with value in a more transcendent sense than just price determination. The attempt to capture this by economists largely takes the form of expanding the catalogue of external effects, as we shall see in the discussion of Sable and Kling (2001) below. A rare attempt within cultural economics to go outside the mainstream positivism in the analysis of arts market value was made by Singer (1988), but this has not really been followed up. The literature on visual art markets currently in cultural economics is dominated by auction pricing regression equations. 
Ruskin wanted living artists' works to be collected by private collectors, while public museums should collect only works by dead artists. Thus we have the domination of the artist by the patron. Modern digital innnovations, such as crowdfunding, have made it possible for the artist to directly elicit patronage from would-be end consumers. Ultimately, humanistic critics of economics, such as Ruskin, had little direct impact on the emerging science of economics, although they may have inspired the eventual appearance of Pigou's Economics of Welfare in 1912 (Pigou 1912 [1932]) which is discussed further below.

\section{The coming of modern economics: general equilibrium and subjectivism}

In general, the move from political economy towards economics, inspired by Marshall, involved a shrinkage, if anything, in the cultural economics agenda. The criticisms by humanists of the economic system of industrialization in the nineteenth century did not spur the emerging mainstream of economics to pay any attention to the cultural needs of the population.

The pioneer of modern partial equilibrium economics, Alfred Marshall, seemed to seek romance in the growth of industry, not in cultural achievements or diversions. Despite the volume of his writings he did not venture any analysis of how culture should be provided. We might defend this on a priority argument based on the hierarchy of needs: that is, basic needs need to be met first; although obviously a cultural economist might wish to dispute this. Marshall did sporadically venture some comments on leisure in general, which clearly includes culture. Here, he proposed an irrationality argument that would suggest some form of correction is needed in cultural markets. In the fifth edition of his Principles of Economics, published in 1907, we find that 'leisure' has three entries in the index, the final of which is separately tagged as 'difficulty of using it well $719^{-} 720^{\prime}$. The full quotation is as follows:

But unfortunately human nature improves slowly, and in nothing more slowly than in the hard task of learning to use leisure well. In every age, in every nation, and in every rank of society, those who have known how to work well have been far more numerous than those who have known how to use leisure well.

The key feature of Marshall's overall method was the use of partial equilibrium rather than the general equilibrium approach chosen by European economists of the time such as Pareto and Walras. Marshall sought practical application of models. The most relevant item in this agenda for us is the development of consumer surplus which would become an element in cost-benefit analyses. The issue of cost-benefit analysis lurks frequently in the field of cultural economics. The strict Marshallian consumer surplus approach would be inapplicable in many areas of cultural economics due to the restrictiveness of its assumptions which were exposed in the 'new welfare economics' of the 1950s. In modern times, cultural economics has for quite some time used 'willingness-to-pay' estimates based on survey instrument 
responses rather than the direct Marshallian surplus taken off a demand curve. This tends to simply bypass the mathematical problems arising if we remove extreme simplifying assumptions.

Marshall's other enduring legacy is that of the analysis of costs in terms of the theories of the firm that are still routinely served up to students in microeconomics textbooks. Many significant and routine works in cultural economics have sought to econometrically estimate cost functions in the Marshallian vein, albeit with sophisticated modern econometrics or augmented specifications (such as the translog function). Given that there was little interest in developing cultural economics when the analysis of costs was being devised, we are unable to find any warnings about whether it can reasonably be applied to cultural enterprise.

The main critique of the cost problem, around the time of Marshall's writing, would have to be derived from Austrian economics, which extends the subjectivism of economics into production as well as consumption. It is very hard indeed to find any Austrian economists putting forward a specifically Austrian view on cultural economics. A rare exception is Cantor (2001), who contests the usual view that government subsidy is needed to protect classical music from the marketplace. He contends that there should be Darwinian competition so that weak cultural work is eliminated and the stronger work prospers. This quite obviously steamrollers the whole oeuvre of Ruskin and is the type of thinking regularly found in conservative think tanks on cultural economics (see, e.g., Sawers 1993). The classic Austrian subjectivist analysis of costs (e.g., Kirzner 1973) applied to culture would suggest that the costs are not exogenous to the producer but are determined by the producer. Examples of this would be the production of blockbuster global musicals and spectacular tours in the heyday of stadium rock by such as the Rolling Stones where there is lavish spending on presentational capital which is not necessary to the product per se. In such cases we then have cost plus pricing by a dominant local monopolist.

Marshall was followed, at Cambridge University, by A.C. Pigou who might be seen as the provider of a synthesis which nullified the attack of humanist critics such as Carlyle, Dickens and Ruskin. This was achieved by extending Marshall's notion of external economies and diseconomies beyond the industry to the wider society. Thus we could now say it was legitimate for economists to consider the dehumanizing (or environmentally degrading) effect of working in a factory, as this was an external cost to society that the firm ideally should be made to pay, at the optimal rate, in terms of maximizing social welfare. The applications to culture are obvious and continue to be prominent in cultural economics, most typically in opposing the Austrian position of Cantor outlined above.

With this extension of the notions of costs, economists could evade a misleading stereotype of being little more than some specialized sort of accountants who issued apologia for markets regardless of their unfortunate and dehumanizing 
tendencies. However they did not, at this time, seek to use it as a justification for special intervention in cultural markets.

\section{The Great Depression era}

The inter-war period brought great uncertainty to economics due to the collapse of the world economy and the not unrelated damage caused by conflict and reparations in the defeated nations. The key notable developments at this time are rather curious with respect to cultural economics. In terms of evolution, Keynes's (1936) General Theory would seem to be a very predictable development. That is, he tried to produce an explanation for persistent long-term unemployment in a free market economy, thus undercutting Smith's invisible hand and the full-blown mathematization of it in general equilibrium models. In doing this, he was attempting to bring into the mainstream the kind of problems addressed by Marx and a band of heretics and mavericks outside the established economics profession: that is, the instability and possible long-run unsustainability of free market capitalism.

Keynes's main contribution has little direct bearing on cultural economics, although it could have been used to extrapolate the counter-cyclical public spending to smooth out the business cycle, as in the argument that we might be better off spending to correct an unemployment disequilibrium by supporting culture rather than digging random holes in the ground with idle men.

With Keynes and other UK economists of the inter-war period we find people with great interest in culture and its advocacy, yet they seem not to make the next step of applying their economic thinking to it. In his life, Keynes was a great aficionado of the arts who moved in cultural circles; his wife was a ballet dancer, and he moved in the circles of the Bloomsbury set who included the novelist Virginia Woolf. Despite this, he did not see any need to bring his economic thinking to bear on the cultural sector as such, and we will recall his oft-quoted remark that economists should aspire to being like dentists. This would imply that they should not be invading the space of philosophers and others who might deal with aesthetic and cultural matters. The later incursion of positivist methodology into economics from Popper via Friedman (1953) supports this, as cultural advocacy would be seen as 'normative' not 'positive'.

Keynes seems to erect a convincing argument for why he did not seek to produce any cultural economics, as his overall view of economics would have made this inappropriate. One would be tempted to conclude that the core explanation for Keynes not contributing to cultural economics as a body of thought lies in his preoccupation with macroeconomics rather than individual decision-making. He struggled to produce a consistent analysis of the behaviour of firms and organizations in the General Theory. This is famously reflected in the lapse into very ad hoc behaviouralist analysis of firms in terms of 'animal spirits' rather than optimization. This has been taken up in later times by Post-Keynesian economics, but not by cultural economics, which has consistently toed the neo-classical line. 
The world may have been collapsing and hurtling towards a catastrophic war in the 1930s, but other economists still found time for refined ruminations on the nature and significance of their subject, as enshrined in the title of the work by Lionel Robbins (1932; and with meaningful revisions to the 1935 edition). Robbins made the claim that to be a 'good' economist, one would need to be more than just an economist; specifically, that one ought to have some cultural awareness and participation. This does not take us up to the application of economics to culture, as Robbins did not make it explicit that the good economist should contribute to the analysis of culture rather than just being a consumer of it. Significantly, Robbins was an advocate of wider access to higher education, which is usually seen as affiliated with the expansion of the cultural sector.

Contemporary to Robbins, Fraser (1937) also explored the deeper questions about the purpose and meaning of economics, with specific reference to the use of language. Although he provides many examples of different types of activity in terms of trying to identify what is uniquely 'economics' about a problem or its analysis, he does not branch out to a consideration of culture at any point. So we may conclude that a 'crisis' in the subject of economics in the 1930 sid not tend to any evaluation of whether it needed to be more 'cultural'.

\section{More modern times}

The new welfare economics and the emergence of law and economics potentially raises many problems in cultural economics in the normative area. Simple Pigovian welfare economics still lingers on in basic microeconomic courses but it has been subject to considerable battering in terms of the purely theoretical content.

First, we have the serious difficulty of devising a measure of consumer surplus when the Marshallian assumptions do not hold and we must look to compensating variation and equivalent variation. In practice, applied cultural economists have followed a similar path to environmental economists and spent a long time using contingent valuation and willingness-to-pay methods to elicit values without too much explicit link to the theoretical problems of measurement. Currently these methods are declining somewhat due to the increased vogue of happiness measurement.

In terms of policies to produce Pareto improvements by intervention in the cultural economy, a serious obstacle arose with the presentation of the theory of the second best. Lancaster and Lipsey (1956-57) codified this problem which had been lurking for some time. That is, the derivation of conditions for welfare-improving 'corrections' to market failure is very complex, meaning that traditional Pigouvian policies such as offering subsidies may make things worse instead of better. There are no simple rules which can be applied in terms of how prices should be set, or incentives provided in publicly funded or supported areas.

These problems will apply in the area of public goods provision as well as for private goods with some public goods properties. Cultural economics research 
still seems, surprisingly, to neglect the problem of second best. For example, Sable and Kling (2001) seek to promote the idea that some culture such as heritage has multiple sources of benefits, giving rise to a 'double public good' (DPG) argument. They define the DPG as the combination of preservation and access, but also throw in some remarks about 'symbolic' value and 'ambience' (ibid., p. 83). Their model and derivations are really then the basic textbook market failure argument due to an externality, but with a claim that there are special 'double' types of externality. I should add that 'double' here is not a numerical claim about any values involved, just that there are double grounds for intervention. Their aim is to say that 'more' preservation increases welfare. However, one might say that this exemplifies the tendency to bourgeois hegemony shown in earlier cultural economics. It is not obvious why soap operas and supposedly low-brow music (that is, anything at all in the economy) cannot be generators of the same sorts of 'double' externalities.

\section{The stirrings of cultural economics: Baumol, Blaug, Peacock and the ACEI}

The proper beginning of cultural economics takes place in the 1960s, and as such coincided with an expansion of the number of professional economists and in the higher education and university sectors. The most prominent exponents and leaders were economists distinguished by a wide range of achievements in other areas of economics. They would continue their work in these areas rather than becoming pure specialists in the cultural economics area. They were also influential figures in the Association of Cultural Economics International (ACEI) and the associated Journal of Cultural Economics (JCE), although these projects have been led by others. The main such economists were William J. Baumol, Mark Blaug and Sir Alan Peacock (see, e.g., Baumol and Bowen 1966; Blaug 1977, 1978; Peacock 1969, 1998; Peacock and Rizzo 2008).

The most enduring specific contribution from this group is that of Baumol in terms of his 'cost disease', which argues that due to differential rates of technical progress, the cultural sector will find the terms of trade shift against it versus other sectors and thus be subject to secularly increasing cost pressures which may lead to its decline in the market. It is fair to say that their cultural economics work was largely around public sector provision and intervention. They were actively involved in government bodies in these areas, but unlike Keynes and Robbins they brought their economic knowledge to bear. Thus we find that cultural economics is finally coming to fruition.

The JCE was established in 1977 and was an independent operation run by Professor William Hendon at the University of Akron, Ohio. Hendon typifies one strand in the cultural economics field, which is participation from somewhat contiguous fields which have some degree of interdisciplinarity with economics: in this case, the urban studies or geographical area; or in other instances, marketing. The journal was afilliated with the ACEI which was independently producing conference volume proceedings via Hendon. 
The initial profile of JCE in the wider economics profession was low and it did not grow notably during the Hendon era. The profile of the journal has increased since being taken on by a major international publisher (Springer). It has recently also gained more of a foothold in the Association of Business Schools (ABS) list of journals often used by university management in assessing academic performance. It is now ranked there as a category 2 journal, that is, publishing fully refereed, original research of an acceptable standard. Being a specialist field journal means that it will be difficult to rise above this level; however, the current position is a distinct advance for the subject area.

\section{Establishment as a professional category and a community of scholars}

The Journal of Cultural Economics is now published four times a year by Springer. The Association for Cultural Economics has a biannual conference. After much struggle, cultural economics gained a code within the official bibliographic system of professional economists determined by the American Economic Association for use in its Journal of Economic Literature. As a latecomer to the mainstream cataloguing of economics, the code lurks at the bottom of the alphabet $\left(\mathrm{Z}_{4}\right)$.

The emergence of textbooks is a clear signifier of the codification of a field of knowledge. In the present case it is useful to look at them as they have been written by prominent active figures in the field whose research is incorporated in the text in the way that pedagogic bodies call 'research-embedded teaching'. Curiously, several of the people involved in these textbooks were quite heavily involved in labour market related areas (Grey, Throsby, Towse). The arrival of cultural economics textbooks coincides with the emergence of the ACEI. The first text is by Throsby and Withers (1979), which runs through the application of basic microeconomics to some issues. Most notable is the fact that the title references only 'the performing arts', not the cultural sector as a whole.

The subsequent growth of textbooks has not been rapid, due to the lack of sufficient dedicated modules on the subject being taught. The next general work is by Heilbrun and Gray (2001). Their text is in five parts: I The Arts Sector; II The Microeconomics of Demand and Supply; III Fine Arts and Museums; IV Public Policy Towards the Arts; and V Art, Economy and Society. Despite the appearance of the word 'culture' in the title of the book, it does not appear in the names of these sections, whilst 'arts' does. Fourteen of the 17 chapters include either 'art' or 'arts' in the title, but none of them contains the word 'culture' in the title. The topics covered are chiefly about elitist or bourgeois conceptions of 'high' art. When we come to mass media and broadcasting the chief reason for an interest is how these can be used to help cultivate tastes for the more elitist and bourgeois forms of culture - that is, 'the Arts' - which this book is clearly about rather than culture in general.

Towse (2010) has 20 chapters in five sections: I. General Issues in Cultural Economics (production and consumption, with Chapter 7 being 'Welfare Economics and Public Finance'); II. The 'Traditional' Economics of Arts and Heritage; III. Artists' 
Labour Markets and Copyright; IV. The Creative Industries (music, films, broadcasting, and so on); V. Conclusion.

In contrast to Heilbrun and Gray, the chapter titles feature the word 'culture' and not 'the arts'. Each chapter title starts with 'The Economics of .... The labour markets section has a chapter title which explicitly mentions theory, but the others do not. Thus we can see a move on from the more elitist coverage of Heilbrun and Grey into popular culture. This is reflected in the promotional material, although the endorsement by Baumol refers to Towse's knowledge of 'The Economics of the Arts'; and her use of the term 'traditional' in quotation marks for Part II acknowledges that there has been a move on from the scope represented in Heilbrun and Grey; although one has to wonder in what sense it is 'traditional', as it was simply a case of limited scope of topic, not an approach which has been abandoned in favour of something non-traditional.

Ultimately the coverage cultural economics now has, and the approach taken, looks largely like a sub-sector of industrial economics, with some elements of public sector economics, although an industrial economics text would invariably have such elements. What we get here is mainly an explanation of the price of things along with statistical profiles of the nature of the industries where the pricing occurs (given that wages and royalties are also prices of things). At the present stage, work in the field follows this style as it is dominated by applied empirical studies of some type, and the dominant methodology is that of the econometric techniques applied by economists in other areas of applied economics. Typically, some kind of equation is estimated, using multiple regression, where a dependent variable of interest is regressed on 'explanatory' variables.

\section{What is cultural economics?}

So far we have skirted around giving a full answer to this question. Somewhat inevitably, it is addressed by textbooks and handbooks. In textbooks this usually involves reference to the creative industries and the creative economy (and in earlier terms to the 'arts' or 'lively arts'). Definitions of the creative sector are founded on the notion that anything involving ideas, rather than manual labour, can potentially be included. In the work of Richard Florida, this has led to some extravagant estimates of the share of the creative economy in the total economy (for a critique of this, see Cameron 2011).

'Cultural economics' can be a confusing term as it is not automatically 'cultural' at all in the sense that others might understand the term, such as those working in cultural studies or cultural anthropology. Applying standard economic models to the purchase of something we define as a cultural good does not automatically make what we have done cultural economics. Saying this asserts that cultural economics is something special, unlike say labour economics or industrial economics. This would seem obvious, as those are simply fields of specific activity to 
which standard economics is applied. Nonetheless it could still be argued that those fields need a broader identity than being an econometric playground for workaday journal material. For example, there are many sociological aspects to labour markets. Use of the long-established works on organization by Williamson, Coase and others should bring a more thorough overhaul of those fields. Pursuing this kind of thinking, we could go to the opposite position that all economics should be cultural economics, opening up the shift to a new paradigm possibly taking its lead from such economics anthropological studies as Douglas and Isherwood (1979). Currently the field of cultural economics displays little sign of this, although there are isolated workers such as Maria Bianchi (1997). Part of the problem may be the neglect of the social nature of culture, as culture intrinsically involves sharing with other people. It is not obvious that such sharing can be captured adequately by standard consumption externality approaches; that is, there is an issue of 'meaning' to cultural consumers which is at risk of being swept under the carpet by the incoming tide of happiness research empiricism. In summary, we may say that the definition of cultural economics brings us similar problems to those found in a field like feminist economics, which struggles to escape from being simply mainstream econometric studies of gender-specific topics such as labour market discrimination and prostitution.

\section{The daily agenda of cultural economics in modern times}

I give here a brief overview of the kind of work which is currently found in cultural economics research. More detailed accounts on some specific topics will be found in Chapter 3 onwards. The current daily agenda is still heavily focused around basic supply and demand considerations, but with forays on the demand side into some wider social interaction issues often occasioned by digital information innovation.

In particular, there is still an ongoing interest in estimating the price elasticity of demand in participation areas such as visits to museums and art galleries, and for live performance, particularly theatre and opera. There have been some more detailed attempts to look at whether high prices are a genuine barrier to such consumption. This can be assessed by giving people highly subsidized or free (voucher) entry or allowing pay what you want (PWYW) performances where individuals can donate rather than pay set prices. In practice, PWYW schemes will still have a floor price. It is perhaps interesting that even now such schemes are treated as startling innovations by the media and practitioners in the arts sector (at least in the UK). Examples such as Kolb (1997) show that there can be failures in trying to sell 'high' culture goods using strong price incentives. This might be an indication of problems arising from the presence of experience goods which may be subject to rational addiction processes (Becker and Murphy 1988) that require human capital investment in the form of appreciation capital.

There has been a flow of empirical studies since Cameron (1999) on the rational addiction approach for cultural goods. In this model, the individual may build up 
a stock of 'appreciation capital' through learning about their consumption activity, and through learning about it by experience. The rational addiction approach also induces more consideration of experience goods aspects of consumption goods particularly in terms of the difficulty of acquisition of knowledge. There continue to be many studies of the influence of the writings of critics in cultural works, and more recently the impact of word of mouth from lay, fan and consumer reviews.

Direct studies of price-setting now often tend to be of auctions, whether it be for rare manuscripts, musical instruments, broadcasting licences or fine art. In many types of auctions the final selling price is determined by the marginal valuation of the keenest buyer, which is relatively easily studied using econometric models of the broadly hedonic type where we simply include attributes of the item sold. The arrival and growth of e-Bay allows the marginal (deciding) buyer to receive a 'consumer surplus'.

Besides prices, the basic primary factor of interest, in demand, to economists is income. For cultural economists, income (as with price) operates on the basis of the standard theoretical model of demand. The Becker allocation of time model facilitates different computations of price and income elasticity due the use of the idea of 'full income'. This is not always taken into account.

In standard studies of demand for cultural goods (e.g., Lévy-Garboua and Montmarquette 2011), the income elasticity is usually shown to be high (not below 1 , and sometimes much higher). There is an ad hoc tendency in economics (found in some basic micro theory books) to refer to goods with an income elasticity of greater than 1 as 'luxuries'. This is done because such goods will take up an increasing share of income as income rises. A recent example of such luxury good thinking is the attempt by Kochkina and Popova (2017) to establish, from regression results, whether books in Russia have been luxuries. It needs to be borne in mind that this does not equate in an obvious way with the lay conception of a luxury, and this again reflects the tendency to overlook social construction of behaviour in cultural economics.

Gary Becker's 'economics of the family' or 'household production model' brought to the attention of economists the problem of intra-household income distribution. Cultural consumption may be shared by family members, so it is not obvious whether there is a clear relationship between the net or gross income of an individual in household surveys and their actual command of resources if they are in a family unit.

Work from government arts support agencies (see, e.g., Bunting et al. 2008) provides wider evidence on socially conducive and inhibitory factors in consumption. This survey-based report finds the following not to be significant deterrents of consumption: disability status, rural or urban status of area, and vehicle access. On the other hand, education, being white and being female have statistically significant positive relationships with likelihood of consumption. 


\section{Supply}

In general the convenient fiction of a supply curve is a problem for cultural economics as there is seldom perfect competition to any broad degree. Therefore it is not usually of much use to apply supply-and-demand analysis. So we may note that the textbooks, and Throsby (1994), talk about production and consumption in their overviews rather than supply and demand. Given this, the study of supply behaviour is often about individual institutions or types of institutions such as museums and theatres, and tends to focus on issues of efficiency and costs. The conclusion could be drawn from some of these studies that resources could be saved if the mixture of sizes of organization could be altered; for example, if some small units were made larger and some of the larger units were made smaller.

Studies of production units focus on static efficiency or on the matter of technical progress. The measurement of technical progress is a problem in all economics, and in the cultural area even questionable proxies such as patents filed and research and development (R\&D) expenditure, which are regularly used, are not available. We have an ongoing unsolved problem, since Gapinski (1984) found that the Royal Shakespeare Company had not made cost savings from technical progress, by assuming that it grows at a constant rate over time.

\section{Where are we now?}

We have covered, in this chapter, the history of ideas with respect to cultural economics, its present broad agenda and the difficulties in defining the field precisely. As indicated earlier, I return to the content of the paper by Throsby (1994) as a reference point for where we are now. He makes three main points:

1. There are numerous non-trivial theoretical and empirical problems yet to be solved.

2. We need better data. He further claims that existing data has been 'wrung dry' and that cultural economics need to be more actively involved in the collection of the data they use.

3. Further on point 1 , he says the subject is too wide to be encapsulated by neoclassical economics, and there is a range of issues in other subjects such as philosophy, aesthetics, history, sociology and politics.

As far as point 1 goes, we may be in a worse position due to the changes in the economy from digitization which are still being approached with standard neoclassical economics. On point 2, we verge into 'yes and no' territory as there are more types of data on more things from more territories, but more and bigger data is not always better. So, his point about active involvement is a very serious one, inasmuch as data comes from existing sources. There is here a serious effort and cost problem facing the researcher. As I have indicated at several points, number 3 is still a very serious problem. Little progress is being made on it at this point in time. 


\section{Conclusion}

This chapter has given an overview of the development of ideas in the the field of cultural economics. Of necessity, this has involved pointing out that there has often been a significant lack of cultural economics despite the presence of relevant tools, and problems to apply them to. I would maintain that this is a useful exercise in itself and helps to give us perspective on the problems faced in trying to construct a more meaningful and progressive cultural economics. It may also illuminate the problem of getting other economists outside the cultural economics field to take it seriously. Although it is abundantly clear that there is a large body of relevant work, and appropriate empirical tools, there remain significant future challenges which are not currently being addressed other than in some narrowly specific areas. In the next chapter I take an overview of the challenges emerging specifically from technological change, developments in the wider field of economics, and the global political situation.

\section{References}

Bacon, R. and Eltis, W. (1976). Britain's Economic Problem: Too Few Producers. London: Macmillan.

Balestrino, A. (2011). On Economics, Leisure, and Much More. In Cameron, S. (ed.), Handbook of the Economics of Leisure. Cheltenham, UK and Northampton, MA, USA: Edward Elgar Publishing, pp. 15-37.

Becker, G. (1965). A Theory of the Allocation of Time. Economic Journal, 75, 493-508.

Becker, G. and Murphy, K. (1988). A Theory of Rational Addiction. Journal of Political Economy, 96, $675-700$.

Baumol, W.J. and Bowen, W.G. (1966). Performing Arts: The Economic Dilemma. New York: Twentieth Century Fund.

Bianchi, M. (1997). Collecting as a Paradigm of Consumption. Journal of Cultural Economics, 23(4), $275-289$.

Blaug, M. (1977). Rationalising Social Expenditure - The Arts. In Posner, M. (ed.), Public Expenditure: Allocation between Competing Ends. Cambridge: Cambridge University Press, pp. 205-220.

Blaug, M. (1978). Why Are Covent Garden Seat Prices so High? Journal of Cultural Economics, 2(1), $1-20$.

Bourdieu, P. (1984). Distinction: A Social Critique of the Judgement of Taste. London: Routledge.

Bourdieu, P. (1986). The Forms of Capital. In Richardson, J.G. (ed.), Handbook of Theory and Research for the Sociology of Education. New York: Greenwood Press, pp. 241-258.

Bunting, C., Chan, T.W., Goldthorpe, J., Keaney, E. and Oskala, A. (2008). From Indifference to Enthusiasms: Patterns of Arts Attendance in England. Arts Council, England.

Cameron, S. (1999). Rational Addiction and the Demand for Cinema. Applied Economics Letters, 6, 617-620.

Cameron, S. (2011). The Creative Sector and Class of Society. In Runco, M. and Pritzker, S. (eds), Encylopedia of Creativity, 2nd edition. Amsterdam: Elsevier, pp. 282-287.

Cameron, S. (2015). Music in the Marketplace: A Social Economics Approach. Abingdon: Routledge.

Cameron, S. and Thorpe, A. (2004). Legislation for Economic Sclerosis: Are Lawyers a Baleful Influence on Growth Rates? Kyklos, 57(1), 45-66.

Cantor, P. (2001). An Interview with Paul Cantor. Austrian Economics Newsletter, 21(1). https://mises. org/library/austrian-economics-and-culture-interview-paul-cantor (accessed 25 August 2018). 
Courty, P. (2000). An Economic Guide to Ticket Pricing in the Entertainment Industry. Recherches Économiques de Louvain - Louvain Economic Review, 66(1), 167-192.

Courty, P. (2003). Some Economics of Ticket Resale. Journal of Economic Perspectives, 17(2), 85-97.

Douglas, M. and Isherwood, B. (1979). The World of Goods. London: Allen Lane.

Florida, R. (2002). The Rise of the Creative Class: And How It's Transforming Work, Leisure and Everyday Life. New York: Basic Books.

Fraser, L.M. (1937). Economic Thought and Language: A Critique of Some Fundamental Economic Concepts. London: A. \& C. Black.

Frey, B.S., Benesch, C. and Stutzer, A. (2007). Does Watching TV Make Us Happy? Journal of Economic Psychology, 28(3), 293-313.

Friedman, H. (1953). The Methodology of Positive Economics. Essays in Positive Economics. Chicago, IL: University of Chicago Press, pp. $3-43$.

Gapinski, J.H. (1984). The Economics of Performing Shakespeare. American Economic Review, 74, 458-466.

Geoghegan, V. (1981). Reason and Eros: The Social Theory of Herbet Marcuse. London: Pluto Press.

Ginsburgh, V.A. (2001). The Economics of Art and Culture. In Smelser, N. and Baltes, P. (eds), International Encyclopedia of the Social and Behavioural Sciences. Amsterdam: Elsevier. https:// ideas.repec.org/p/ulb/ulbeco/2013-1869.html.

Ginsburgh, V. and Throsby, C.D. (2006). Handbook of the Economics of the Arts and Culture. Amsterdam: Elsevier, North-Holland.

Heilbrun, J. and Gray, C.M. (2001). The Economics of Art and Culture, 2nd edition. Cambridge: Cambridge University Press.

Henderson, W. (200o). John Ruskin's Political Economy. London, UK and New York, USA: Routledge.

Keynes, J.M. (1936). The General Theory of Employment, Interest and Money. London: Macmillan.

Kirzner, I. (1973). Competition and Entrepreneurship. Chicago, IL, USA and London, UK: University of Chicago Press.

Kochkina, N. and Popova, E. (2017). Are Books Luxury Goods in Russia or Not? National Research University Higher School of Economics Perm, Perm territory, Russian Federation.

Kolb, B.M. (1997). Pricing as the Key to Attracting Students to the Performing Arts. Journal of Cultural Economics, 21, 139-146.

Lancaster, R.G. and Lipsey, K. (1956-57). The General Theory of Second Best. Review of Economic Studies, 24(1), 11-32.

Lévy-Garboua, L. and Montmarquette, C. (2011). Demand. In Towse, R. (ed.), A Handbook of Cultural Economics, 2nd edition. Cheltenham, UK and Northampton, MA, USA: Edward Elgar Publishing, pp. $177-189$.

Lim, Sang-Oh (2011). John Ruskin's Cultural Economics. Review of Culture and Economy, 14(1), 3-19.

Marshall, A. (1907). Principles of Economics, 5 th edition. London: Macmillan.

May, C. (2010). John Ruskin's Political Economy: 'There is No Wealth but Life'. British Journal of Politics and International Relations, 12(2), 189-204.

Michalos, A. and Kahlke, P.M. (2008). Impact of Arts Related Activities on the Perceived Quality of Life. Social Indicators Research, 89, 193-258.

Mill, J.S. (1873 [2018]). Autobiography. Edited by Mark Philp. Oxford World's Classics. Oxford: Oxford University Press.

Peacock, A.T. (1969). Welfare Economics and Public Subsidies to the Arts. Manchester School of Economics and Social Studies, 37(4), 323-334.

Peacock, A. (ed.) (1998). Does The Past Have A Future? The Political Economy of Heritage. London: Institute of Economic Affairs.

Peacock, A.T. and Rizzo, I. (2008). The Heritage Game: Economics, Policy and Practice. Oxford: Oxford University Press. 
Pigou, A.C. (1912 [1932]). Economics of Welfare, 4th edition. London: Macmillan.

Robbins, L. (1932). An Essay on The Nature and Significance of Economic Science. London: Macmillan.

Ruskin, J. (1857 [1905]), A Joy For Ever: Being the Substance (with Additions) of Two Lectures on The Political Economy of Art Delivered at Manchester, July 1oth and 13th, 1857. In Cook, E.T. and Wedderburn, A. (eds) (1905), The Works of John Ruskin, Volume 16. London, UK and New York, USA: George Allen, pp. 5-174.

Sable, K.A. and Kling, R.W. (2001). The Double Public Good: A Conceptual Framework for Shared Experience Values Associated with Heritage Conversation. Journal of Cultural Economics, 25(2), $75-89$.

Sawers, D. (1993). Should the Taxpayer Support the Arts? London: Institute of Economic Affairs.

Singer, L. (1988). Phenomenology and Economics of Art Markets: An Art Historical Perspective. Journal of Cultural Economics, 12(1), 27-40.

Smith, A. (1759 [1976]). The Theory of Moral Sentiments, ed. E.G. West. Indianapolis, IN: Liberty Classics.

Smith, A. (1776 [1976]). An Inquiry into the Nature and Causes of the Wealth of Nations, ed. E.G. West. Indianapolis, IN: Liberty Classics.

Throsby, C.D. (1994). The Production and Consumption of the Arts: A View of Cultural Economics. Journal of Economic Literature, 32(1), 1-29.

Throsby, C.D. (2011). The Political Economy of Art: Ruskin and Contemporary Cultural Economics. History of Political Economy, 43(2), 275-294.

Throsby, C.D. and Withers, G.A. (1979). The Economics of the Performing Arts. London: Edward Arnold.

Towse, R. (ed.) (2006). Recent Developments in Cultural Economics. The International Library of Critical Writings in Economics. Cheltenham, UK and Northampton, MA, USA: Edward Elgar Publishing.

Towse, R. (2010). A Textbook of Cultural Economics. Cambridge: Cambridge University Press.

Towse, R. (ed.) (2011). A Handbook of Cultural Economics, 2nd edition. Cheltenham, UK and Northampton, MA, USA: Edward Elgar Publishing.

Winch, D. (200o). Ruskin and Political Economy. Conference paper given at Christ Church, Oxford to celebrate the centenary of Ruskin's death. 